\title{
Public Private Partnerships (PPP) in the Developing World:
} Mitigating Financiers' Risks

\begin{tabular}{|r|l|}
\hline Journal: & World Journal of Science, Technology and Sustainable Development \\
\hline Manuscript ID & WJSTSD-05-2018-0043.R1 \\
\hline Manuscript Type: & Research Paper \\
\hline Keywords: & $\begin{array}{l}\text { Public Private Partnerships (PPP);, Emerging Markets, Bankability, Foreign } \\
\text { Financiers, Risks }\end{array}$ \\
\hline
\end{tabular}


1 Public Private Partnerships (PPP) in the Developing World: Mitigating

2 Financiers' Risks

3 Abstract:

$4 \quad$ A major challenge for foreign lenders in financing PPP infrastructure projects in an emerging

5 market is the bankability of country-related risks. Despite existing studies on country risks in

6 international project financing, perspectives of foreign financiers on bankability of country-

7 specific risks in an emerging market is yet to be explored. Hence, using a mixed methodology

8 approach to research, three PFI/PPP projects in Sub Saharan Africa (Nigeria) were used to

9 investigate the bankability requirements for political risk, sponsor, concession and legal risks

10 in PPP loan applications. Focus group discussions and loan documentations obtained from

11 foreign project financiers with experience in PPP financing in Nigeria were used as sources

12 of evidence. Results identified 22 bankability criteria for evaluating country-related risks

13 (political risk, sponsor, concession and legal risks). These criteria were later put in a

14 questionnaire survey to local and international project financiers with experiences in PPPs

15 within Nigerian. Reliability analysis and significance index ranking were carried out. The

16 significance index ranking helped ascertain the top 7 criteria influencing bankability of

17 country-specific risks in emerging market PPPs. A conceptual "Risk and Bankability

18 Framework" was then constructed from the findings and validated with new data from other

19 PPP financiers in emerging markets. The proposed conceptual framework represents critical

20 parameters for winning foreign financiers' approval for PPP loan applications from emerging

21 market.

23 Keywords: Public Private Partnerships (PPP); Emerging Markets; Risks; Bankability, 24 Foreign Financiers. 


\section{$25 \quad \mathbf{1 . 0} \quad$ Introduction}

26 Despite the huge record of project finance investments in emerging markets (EM) so far 27 (Babatunde and Perera, 2017), financing infrastructures through Public Private Partnerships 28 (PPP) remains risky for foreign lenders (Ameyaw and Chan, 2015). Studies such as Kayaga (2008) and Ameyaw and Chan (2015) have once attributed the associated risks to countryspecific factors relating to the macroeconomic conditions of the project host nations.

31 According to Atmo and Duffield (2014), out of all the current emerging markets (i.e. Brazil, 32 India, Russia, Indonesia etc.); Sub Saharan Africa has a higher country-related risk 33 perception. This situation has therefore hindered her capacity to attract sufficient foreign 34 inflows for prosecuting her PPP infrastructure development ambitions (Briceño-Garmendia et $a l ., 2008)$. Yet, with an estimated annual investment of $\$ 48$ billion finance gap required to meet current infrastructural deficit (Gutman and Chattopadhyay, 2015); PPP remains the only viable option for Sub Saharan Africa (Salawu and Fadhlin, 2015).

Several studies have argued that, foreign financiers' interested in African PPPs must pay attention towards, not only projects' commercial risks but the bankability of country-related risks (Al Khattab et al., 2007; Busse, M. and Hefeker, 2007; Mills, 2010). According to Ncube (2010), bankability in PPP project financing is a big concern despite active roles of multilateral and bilateral agencies in Sub Saharan Africa. In many instances, risks associated with weak credit capacity to obtain foreign loan by indigenous sponsors usually give rise to sponsor risk (Mills, 2010). From foreign financiers' perspective, sponsor risk discourages lenders from financing or compels them to reduce the size of loan to invest in a project'

47 (Mills, 2010). In addition, scenarios such as civil unrest, currency devaluation, leadership 48 instability, weak legal framework for PPP etc. generate real threat of political risk in project 49 financing (Bing et al., 2005, Carrieri, et al., 2006; Busse and Hefeker, 2007). According to 
50 Kayaga (2008), expropriation and government repudiation of contracts seriously limited 51 Africa's PPP growth, with $80 \%$ of PPP contracts attracting disputes and cancelled between 521990 and 2004. Such cancellations usually have sustained impact on a nation's PPP initiative 53 by dampening market confidence in government's commitments (Ncube, 2010).

55 One of the fundamental aspect of PPP arrangements is full compliance with project's output 56 specifications, performance contracts and concession termination clauses (Oyedele, 2013; 57 Khadaroo, 2014). However, given the relatively weak PPP culture, institutional and regulatory frameworks in many Sub-Sahara African economies, failures of compliance may create threats of concession related risks. With huge lender's investments usually at stake in PPPs, contractual infractions and consequent statutory deductions will jeopardize foreign

61 financiers' investments on the such projects. Other important risk factors may emerge in form 62 of legal or regulatory risks. In most cases, such risk arises in situations where construction or 63 operations of PPPs contravene domestic laws of host nations, or problems relating to approval and permits of projects (Sachs et al., 2007; Oyedele, 2013).

66 The overall consequence of these identified country-specific risk factors on foreign 67 financiers' investments in sub-Saharan African PPPs can be quite damaging. As such, a 68 framework for evaluating the bankability of country-related risks in PPPs within an emerging 69 market context has been canvassed (Olsson, 2002; Atmo and Duffield, 2014; Giannetti and 70 Ongena, 2012). Albeit, enormous literatures abound on risks in PFI/PPP generally (Bing et 71 al., 2005; Eaton et al., 2006; Hoffman, 2008; Quiggin, 2004; Hardcastle et al., 2005;

72 Hammami et al., 2006; Khadaroo, 2014). However, much of these studies have focused on 73 projects in advanced economies like UK, Australia, Canada, US etc. (Demirag et al., 2011; 74 Grimsey and Lewis, 2002; Bing et al., 2005; Khadaroo, 2014). Although, few studies exist on 
75 risks in PPP in some emerging economies i.e. China, Indian, Turkey etc. (; Quiggin, 2004;

76 Chan et al., 2014; Sachs, 2007; Giannetti and Ongena, 2012), there is currently no research

77 exploring the bankability of country-related risks in PPP projects in Sub Saharan Africa,

78 especially from foreign financiers' perspectives. This therefore represents a significant gap in

79 knowledge on which basis the current study emerged. The overall aim of this study is to

80 investigate the bankability criteria and associated risk mitigation strategies used by foreign

81 financiers to evaluate country-specific risks in PPP funding applications within emerging

82 market context. The following objectives have been identified for the study:

83 1. To identify relevant lenders' bankability criteria and existing risk mitigation strategies

84 for evaluating sponsor risk, political, concession and regulatory risks in PPP loan

$85 \quad$ applications in an emerging market.

86 2. To confirm wider applicability and overall significance of the identified criteria

87 towards influencing the bankability of country-specific risks in PPP funding

$88 \quad$ applications.

89 3. To propose a "Risk and Bankability" framework model that pairs country-specific

90 risks with bankability criteria and risk mitigation strategies under a robust platform,

91 towards aiding foreign lenders' bankability decision.

92 The study adopts a mixed methodology approach to research (qualitative and quantitative). In

93 other to identify relevant bankability criteria and risk mitigation strategies for evaluating

94 country-specific risks in PPP loan applications in an emerging market, multiple case studies

95 were investigated. The case studies comprised PPP projects in Nigeria that were financed

96 with significant amount of foreign loans. Asides being an emerging market (classified by the

97 World Bank as a MINT nation) and located in sub Saharan Africa, the choice of Nigeria for

98 PPP case studies was based on her increasing portfolio of PPP projects in the region. 
99 Exploring the subjective views of foreign project financiers was therefore carried out via 100 focus group discussions and document analysis. Wider applicability of the qualitative 101 findings was confirmed using questionnaire survey to both local and international project 102 financiers with involvement in Nigeria's PPP projects. A "Risk and Bankability" framework 103 was thereafter developed from the overall findings and validated with new data from project 104 financiers. This model provides a valuable mind-map for foreign financiers and project 105 sponsors desirous of investing in PPPs in an emerging market. The paper is laid out under 106 four major sections. Sections 2 and 3 focus on literature review. Section 4 discusses the 107 research methodology and described the three PPP projects' used as case studies from 108 Nigeria. Section 5 presents the qualitative and quantitative data analysis (from focus group 109 discussions and questionnaire survey), while section 6 discusses the general findings from the 110 study. The last section of the paper concludes the study.

\section{$111 \quad$ 2.0 PFI/PPP Infrastructure Developments in Emerging Markets}

112 Since its proliferation in November, 1992 in the United Kingdom under the name Private 113 Finance Initiatives (PFI), the application of PPP have crossed bilateral and multilateral 114 borders with private sector-led developmental initiatives (Oyedele, 2013, Demirag et al; 115 2011). According to Atmo and Duffield (2014), the last ten years have witnessed a significant 116 drive towards private participation in the delivery of infrastructures especially in developing 117 economies. The increasing provision of public utilities through public private partnerships 118 have made vital infrastructures such as schools, prisons, hospitals, power plants, bridges, toll 119 roads etc. possible in emerging economies. In a recent study by Hammami et al. (2006), the 120 World Bank is reported to have estimated that $20 \%$ of global infrastructure investments 121 amounting to US\$850billion were financed during the 1990s through the PPP strategy in 122 emerging economies. 
123 Additionally, recent findings culled from Thomson Reuters PFI database confirmed that the

124 volume of non-recourse project finance deals in emerging economies reached an all-time high in 2010. More than 200 deals were struck, with a total capital outlay of over US\$130bn across the BRICs (Brazil, Russia, India and China); Europe and the next frontier economies in Africa, Asia, Middle-East and Latin America. However, despite recent popularity, there are mixed fortunes for PPP in emerging markets, considering the significant differences in 129 performances among the EM nations i.e. China, Hong Kong, Taiwan, India, Indonesia, 130 Malaysia, the Philippines, Brazil, Singapore, Sub Saharan Africa etc. (Cavusgil, 1997; 131 Ramamurti and Singh, 2009). Currently, Africa's public sectors still retain the lion's share of 132 infrastructure financing (Briceño-Garmendia et al., 2008). Whereas private-sector led 133 infrastructure finance in Sub-Saharan Africa is still limited to about 5\% -10\% growth with an 134 annual \$48billion financing gap as at 2012 (IFC Report, 2013), the so-called BRIC nations 135 accounts for $62 \%$ of private-sector led infrastructure investments, with $60 \%$ growth trend as 136 at 2008 (Basilio, 2011). See Fig.1 below for distribution of investment in infrastructures 137 among BRICs and other nations across the globe.

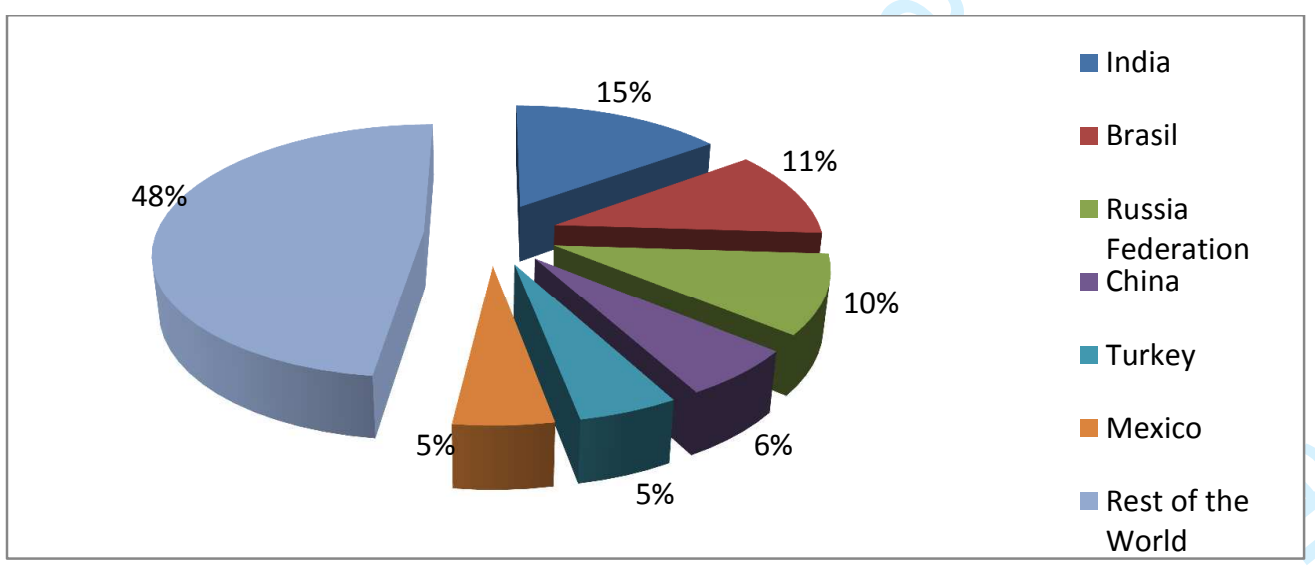

Fig.1 Geographical spread of investments in infrastructure projects in BRICs nations as at 2008 Source: 140

\section{Basilio (2008)}


141 From another perspective, PPP infrastructure procurement in Nigeria has gathered

142 momentum in the last decade, with over 25 infrastructure projects being executed across state 143 and federal levels (Solomon et al, 2015). Since the first wave of PPP projects in Nigeria 144 which was kick-started with the rebuilding of the Murtala Mohammed Airport (MM2) project 145 in 2003 (Ibem, 2010), several major infrastructure projects have been procured through PPP 146 (Mudi et al, 2015). As of now, recent statistics show that about N10trillion has been invested 147 in various PPP projects by different levels of government in the country (Solomon et al., 148 2015). However, despite the current efforts, Nigeria remains behind many other emerging 149 market economies in terms of infrastructural deficit (New telegraph, March 21 ${ }^{\text {st }}, 2018$ ). 150 Recent statistics suggest an annual infrastructure investment of between $\$ 12$ and \$15billion 151 for the next six years is needed in order to meet Nigeria's growing infrastructural deficit 152 (Emmanuel, 2016; New telegraph, March-2018).

\subsection{Risk in PPP Infrastructures in Nigeria}

155 In a study by Royal Society (1983, p.22) cited in Demirag et al. (2011), risk is described as 156 the probability that a specific adverse event will happen at a particular period of time. Risk is 157 also referred to as the possibility that an event, its resulting impact and dynamic interaction 158 turns out against anticipated outcome (Bing et al., 2005). Wang et al. (2004) classified risks 159 in PPP projects into internal and external risks. While internal risks are common with every 160 project such as design risk, construction risk, operation and maintenance risks among others, 161 external risks are negative uncertainties arising due to project's interaction with the 162 environment. Examples of external risks in PPP projects include regulatory risk, concession 163 risk, currency or foreign exchange risk, political or social uncertainties, reputational risk 164 among others (Akintoye et al., 2015; Oyedele, 2013). 
166 According to Liu et al. (2016), although external risks abound in most projects regardless of 167 where they are being delivered, the severity of external uncertainties is higher in emerging 168 market PPP projects. For example, a country like Nigeria which is an emerging economy and 169 currently at the lower-level of PFI/PPP maturity model has been bedevilled by a lot of 170 country-related risk factors (Osei and Chan, 2015). As argued by Akintoye et al. (2015), apart 171 from challenges of packaging bankable PPP projects, Nigeria is faced with problems like 172 politicization of concession contracts, non-competitive bidding, and land acquisition 173 problems. In another related study, Opawole and Jagboro (2016) bemoaned the lack of 174 demarcation of responsibilities among parties in Nigeria's PPP projects. According to them,

175 Poor clarity in duties results in government performing the duties of private contractors

176 which may lead to project failure (Opawole and Jagboro, 2016). While examining barriers to

177 PPP development in Nigeria, Solomon et al., (2015) also suggested foreign exchange risk,

178 high country risk perception, weak risk assessment and management as challenges that need 179 improvement in order to strengthen Nigeria's PPP market. Dominic et al. (2015) argued for 180 better risk allocation that will strengthen service efficiency, including adequate risk transfer 181 to the private sector party for successful PPP implementation in Nigeria. Similarly, Salawu 182 and Fadhlin (2015), whilst assessing risk management maturity of Nigerian PPP contractors 183 condemned the overall risk management maturity level of local contractors. According to the 184 authors, higher risk assessment maturity level is needed to enable improved project 185 performance and reduced uncertainties in project outcomes. Kwofie et al. (2016) aligned with 186 above perspective by suggesting effective risk assessment and stakeholder analysis as 187 essential factors for improving the low social acceptability of many Nigerian PPP projects. 188 
Albeit, Nigeria's Infrastructure Concession Regulatory Commission (ICRC) at the federal

190 level, including some few states (Lagos, Rivers, Cross-River etc.) have made serious strides

191 in some aspects of PPP such as project development and preparation, regulation and market

192 awareness. However, more needs to be done in terms of, not only improving Nigeria's

193 infrastructure portfolio, but also the investment climate for PPP financing to thrive. As such,

194 attracting foreign financiers to PPP opportunities in Nigeria will require more effective

195 approaches in areas of enabling risk awareness, identification, assessment and management.

196 This will ultimately have huge impact on PPP growth in Nigeria and also ensure that more

197 bankable projects that can attract both local and foreign investors are packaged.

198

$199 \quad 4.0 \quad$ Methodology

200 In order to explore the subjective opinions of foreign PPP financiers while also confirming

201 wider applicability of such views, a 'Mixed Methodology Approach' was employed for the 202 study. With mixed methodology, the research team collected both qualitative and quantitative 203 data towards to addressing the research problem (Creswell, 2013). The qualitative phase of 204 the study commenced with multiple case study exploration of three (3) PPP projects in 205 Nigeria. The adoption of case study strategy was based on the unique nature of PFI/PPP 206 projects in which every project is not the same. Additionally, the choice of Nigerian PPP case 207 studies was hinged on her status as an emerging market with growing portfolio of PPP 208 projects in Sub Saharan Africa. However, considering the need to capture diverse opinions of 209 project financiers across various types of PPP projects while also bracketing out 210 presuppositions about the phenomenon (Feagin et al., 1991; Yin, 1994), the study 211 investigated three different types of PPP projects' case studies. A purposive sampling 212 strategy was employed, in order to identify suitable case study projects as well as 213 information-rich participants. Also known as "Judgement Sampling” (see, Coviello and 
214 Jones, 2004), purposive sampling strategy involves deliberate search for informants, based on 215 defined qualities that they possess (Yin, 1994). This sampling approach allowed the research 216 team to leverage on her network of contacts within Nigeria's PPP industry to identify 217 participants and access suitable PPP case studies. Studies such as Grimsey and Lewis (2002), 218 Oyedele (2013); Bing et al. (2005) and Eaton (2006) have all adopted similar sampling 219 method within the realm of PFI/PPP literatures.

221 In more specific terms, the study considered the following criteria in selecting appropriate 222 PPP projects' case studies for the research:

223 i. Selection of Nigerian PPP projects wholly or partly financed by international 224 financiers.

225 ii. Availability of evidence-based financing decisions right from funding applications 226 stage by project sponsors, up till financiers' decision to fund the project;

227 iii. willingness of financiers' team to partake in the study; and

228 iv. Availability of at least three accessible informants (experienced staff in foreign 229 lenders' project finance team), who have been centrally involved in reviewing the 230 PPP funding applications of the selected PPP projects' case studies.

231 v. Study to examine any three PPP projects executed in Nigeria between 2003 until $232 \quad 2014$.

233

234 Based on the above criteria, the three case studies that fulfilled the requirements were a PPP 235 Power Project in South West Nigeria, a PPP Seaport Expansion and Maintenance Project in 236 South West Nigeria and a PPP Hospital Project in South-South of Nigeria. While the PPP 237 power project is a 10 -year concession valued at $\$ 25.5$ million, the seaport expansion project 238 was contracted on 25 -year concession with a project value of $\$ 60$ million. The hospital 239 project in South-South Nigeria is a 10-year concession project with a value of $\$ 37$ million 
240 (see Table 1 for the nature and attributes of the three PPP case study projects). Going further, 241 after careful selection of the case studies and research participants, the study conducted three 242 (3) focus group discussions which were supported with evidences from loan documentations 243 from project financiers' for qualitative data collection (also see Table 1 for attributes of focus 244 group discussion participants). This was achieved after reaching a non-disclosure agreement 245 with the project financiers especially restrictions with respect to revealing vivid information 246 capable of giving out the financiers identity as well as detailed project description. 247 Participants in the focus group discussions comprised financial risk managers, senior credit 248 analysts, heads of structured finance divisions etc. While the focus group discussions 249 facilitated in-depth understanding of lenders' shared opinions concerning the phenomenon, 250 less-sensitive loan documentations were used to confirm the claims made by financiers 251 during the focus group discussions. The focus group discussions lasted an average of 55mins 252 and were tape recorded, transcribed and later analysed using Nvivo10 Software. Various 253 codes and nodes were assigned to different emergent themes within the data while carrying 254 out a thorough thematic analysis. Twenty-two (22) criteria relevant for evaluating the 255 bankability of sponsor risk, political, legal and concession risks were unravelled. This was in 256 addition to identifying some risk mitigation strategies used by project sponsors in most loan 257 applications. Other sub-risk components emerging from the major risk factors during the 258 process of due diligence appraisal were also uncovered. 
Table 1: Attributes of PPP Case Study Projects and Focus Group Discussion Participants

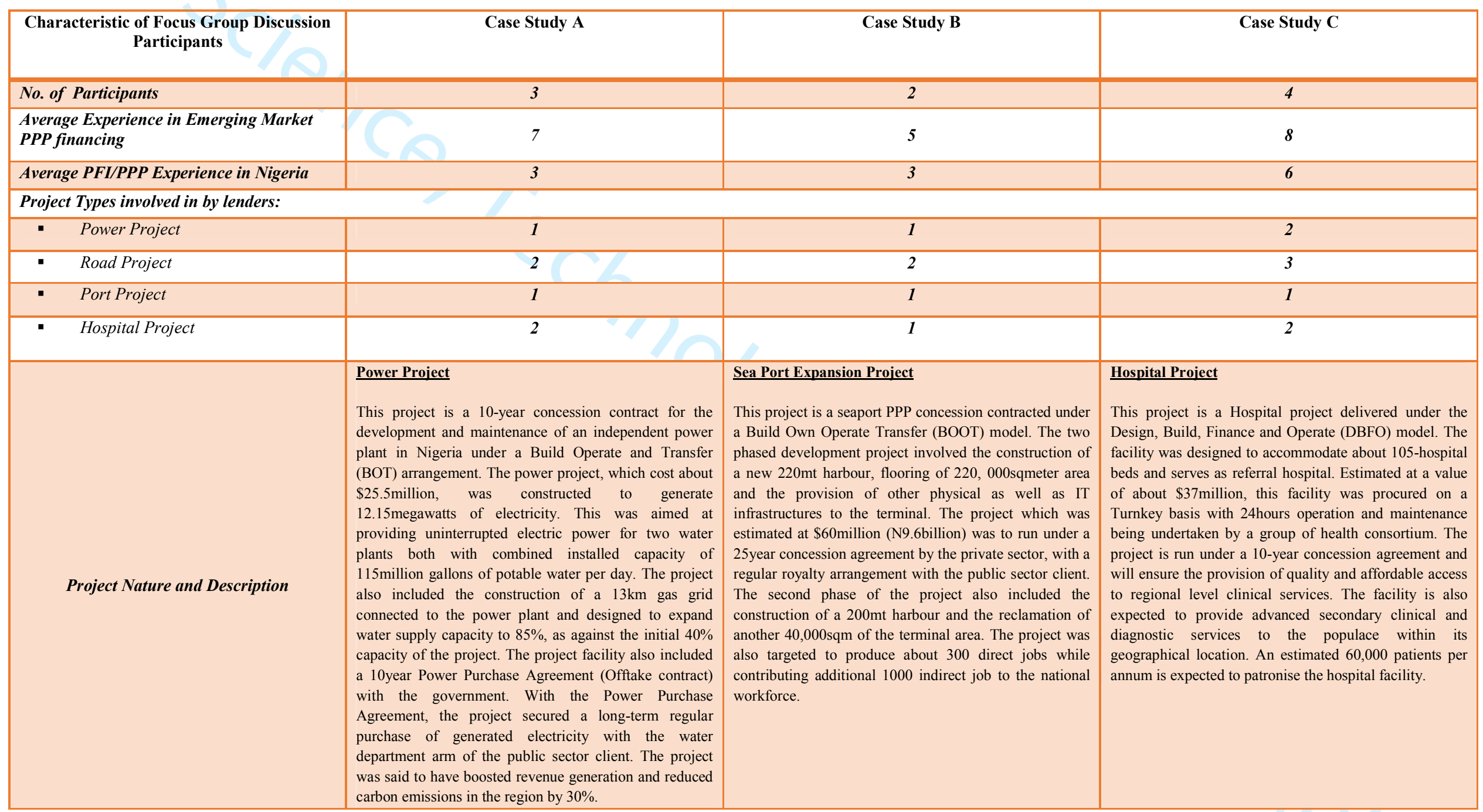


263 The second phase of the study involved questionnaire survey developed from findings from 264 the focus group discussions and loan documentations. This ensured validity and wider 265 applicability of results from the qualitative findings (Oyedele, 2013). The survey targeted 266 wider audiences of local and international project financiers who have been involved in 267 structuring financial packages for PPP projects in Nigeria. Questionnaires were distributed 268 using a snowball sampling approach. As such, the research team built on referrals from their 269 existing contacts among local and international project financiers as well as other subject 270 matter experts involved in PPP financing in Nigeria. The survey respondents comprised 271 senior lenders, financial consultants and infrastructure finance and investment firms. A pilot 272 study involving three separate financiers and two academics with an average of 7years prior 273 experience in PFI/PPP project finance was conducted. The study implemented their 274 feedbacks, which included shortening of sentences and rewording of questions to develop the 275 final questionnaire. In the final questionnaire, respondents were asked to rank the perceived 276 importance of each identified criterion on the bankability of the country-specific risks in PPP 277 funding applications from an emerging market. This was done with the aid of a five-point 278 Likert Scale in which; 5 represented "Most Important" while 1 represented "Not Important".

280 The questionnaire survey was distributed to respondents via email and was accompanied by a 281 letter of introduction detailing the objective of the study. Two hundred and fifty (250) 282 questionnaires were distributed in all, out of which 173 were returned after several reminder 283 emails from June 2013 to March 2015. The rate of response represents $69.2 \%$ of total 284 distributed questionnaires. The return rate was considered suitable for analysis owing to the 285 claim by Oyedele (2013) that survey results lower than 30 to $40 \%$ could be considered of 286 little significance and biased. Out of the returned questionnaires, twenty-seven (27) were 287 incomplete and so rejected, leaving us with $146(58 \%)$ usable questionnaires from senior 
288 lenders, infrastructure finance experts and financial advisory consultants. Among the 289 questionnaire respondents, 71 were senior lenders, 49 of them were infrastructure finance 290 experts while the remaining 26 were financial advisory consultants (see Table 2 for 291 demographics of survey respondents). On average, all the respondents have 11.7years of 292 experience in project financing in emerging economies. With the aid of Statistical Package 293 for Social Sciences (SPSS), the result of the survey was analysed. Reliability analysis to 294 determine whether the variables were true measures of the construct was carried out. This 295 was then followed by correlation analysis and significance index ranking to ascertain the 296 subjective importance (based on lenders' perception) of each bankability criterion identified 297 in the study. Results from the study were later used to develop a "Risk and Bankability 298 Framework". However, in order to ensure reliability and validity of the proposed framework 299 model, the study validated it with three new PPP Projects in Nigeria. The three projects 300 comprised a \$25 million Waste to Energy PPP project in south west of Nigeria, a \$703 301 million BOT Bridge project in South East/South-South of Nigeria as well as a $\$ 150$ million 302 PPP port project in South West Nigeria. Using snowball sampling, the research team built on 303 referrals from their exiting contacts to access new international project finance experts 304 involved in these projects. The study obtained less-sensitive loan documentations from the 305 financiers to validate the model. 


\begin{tabular}{|c|c|}
\hline Variables & Sample Size \\
\hline Total Number of Respondents & 146 \\
\hline \multicolumn{2}{|l|}{ Type of Organisation } \\
\hline - Senior lenders (Staff Members of banks) & 71 \\
\hline - Infrastructure Financiers & 49 \\
\hline - $\quad$ Financial Advisory & 26 \\
\hline \multicolumn{2}{|l|}{ Years of Experience in PPP Project Finance } \\
\hline$<1$ & 3 \\
\hline $1-5$ & 35 \\
\hline $6-10$ & 47 \\
\hline $11-15$ & 33 \\
\hline $16-20$ & 21 \\
\hline$>20$ & 7 \\
\hline
\end{tabular}

\subsection{Data Analysis and Findings}

This section presents analysis of qualitative and quantitative findings from the study. It commences with the qualitative analysis of loan documentations and focus group discussions conducted with foreign lenders involved in financing PPP projects in Nigeria. Immediately

315 following the qualitative analysis is the quantitative analysis of questionnaire survey 316 distributed to wider audiences of local and international project financiers as well as other 317 subject matter experts involved Nigeria's PPPs and other emerging economies.

\subsection{Qualitative Data Analysis}

319 The data analysis commenced with the qualitative aspect of the study. The focus group 320 discussions transcripts were analysed using Nvivo 10 software. The author set out to 321 investigate suitable criteria influencing the bankability of four major risks (sponsor risk, 322 political, concession and regulatory risks) common with emerging market PPPs. Thematic 323 analysis of data transcripts was carried out using various coding and nodes. After exhaustive 324 analysis, 22 relevant criteria influencing bankability of political risk, sponsors, concession 
325 and regulatory risks were unravelled (see, Table 3 for bankability criteria and some

326 mitigations strategies for evaluating country-related risks in PPPs). These bankability criteria,

327 as argued by most focus group discussants, are crucial towards influencing bankability of the

328 identified risks and foreign lenders' loan approval for PPPs in an emerging market.

329

330 In addition, the qualitative analysis also produced a couple of existing risk mitigation 331 strategies often put forward by project sponsors in PPP loan applications in emerging 332 economies, coupled with various sub-risk components resulting from the four major risk 333 factors (Sponsors risk, political, concession and regulatory risk). According to many of the 334 participants, where PPP loan applicants had offered risk mitigations that are not considered 335 critical to bankability by the lenders, such mitigation strategy only give "more advantage" to 336 the lenders. However, the important bankability criteria to lenders are clearly and explicitly 337 requested from project sponsors (See Table 3).

338 Table 3: Analysis of Lenders' Bankability Criteria Adopted for Evaluating for Case Studies 339 
Table 3: Analysis of Lenders' Bankability Criteria Adopted for Evaluating for Case Studies

\begin{tabular}{|c|c|c|c|c|c|}
\hline \multirow{3}{*}{ Risk Factors (RF) } & \multirow{3}{*}{$\begin{array}{c}\text { Risk Mitigation Strategies Proffered by Project } \\
\text { Sponsors }\end{array}$} & \multirow{3}{*}{$\begin{array}{c}\text { Lenders Bankability Criteria for Project } \\
\text { Appraisal }\end{array}$} & $\begin{array}{c}\text { Case Study } \\
\text { A } \\
\end{array}$ & $\begin{array}{c}\text { Case } \\
\text { Study B }\end{array}$ & $\begin{array}{c}\text { Case } \\
\text { Study } \\
\text { C }\end{array}$ \\
\hline & & & Focus Group & Focus Group & Focus \\
\hline & & & (1) & (1) & (1) \\
\hline \multirow{7}{*}{ Sponsor Risk } & Sponsor presents full financial guarantee. & More Advantage & $\checkmark$ & $\checkmark$ & \\
\hline & $\begin{array}{l}\text { Sponsor's background check, credit history and } \\
\text { experience in project finance contracts }\end{array}$ & $\begin{array}{l}\text { Sponsors with track record of successful project finance } \\
\text { contracts delivered on schedule and within budget }\end{array}$ & $\checkmark$ & $\checkmark$ & $\checkmark$ \\
\hline & $\begin{array}{l}\text { 3rd party debt guarantee in form of corporate/Bank } \\
\text { guarantee }\end{array}$ & $\begin{array}{l}\text { Bank-financed guarantee facility or Pre-completion } \\
\text { Guarantee. }\end{array}$ & & $\checkmark$ & $\checkmark$ \\
\hline & Not Provided/Negotiated & $\begin{array}{l}\text { Mix of management skills and experience demonstrated by } \\
\text { or available to the sponsors }\end{array}$ & $\checkmark$ & $\checkmark$ & $\checkmark$ \\
\hline & Not Provided/Negotiated & Sponsor with well-established relationship with a lender & $\checkmark$ & & $\checkmark$ \\
\hline & Front-ended equity contribution & Satisfactory Equity contribution by the sponsor & $\checkmark$ & $\checkmark$ & $\checkmark$ \\
\hline & Not Provided/Negotiated & $\begin{array}{l}\text { Equity contributions must be available either in cash or in a } \\
\text { blocked account. }\end{array}$ & & $\checkmark$ & \\
\hline \multirow{7}{*}{$\begin{array}{l}\text { Country/ } \\
\text { Political } \\
\text { Risk }\end{array}$} & $\begin{array}{l}\text { Supervision of emerging market risk exposure by Lenders' } \\
\text { home country's Central Bank. }\end{array}$ & More Advantage & & $\checkmark$ & $\checkmark$ \\
\hline & $\begin{array}{l}\text { Bank's Internal Country Risk committee to periodically } \\
\text { determine appropriate levels of country risk limits }\end{array}$ & Transfer of Political Risk to Export Credit Agency (ECA) & $\checkmark$ & $\checkmark$ & \\
\hline & $\begin{array}{l}\text { Country/Political risk insurance from private sector } \\
\text { insurers }\end{array}$ & $\begin{array}{l}\text { Country Capacity/Political Risk Insurance from private } \\
\text { sector insurance }\end{array}$ & $\checkmark$ & & \\
\hline & Not Provided/Negotiated & $\begin{array}{l}\text { Raising a part of the project loan from banks in the host } \\
\text { country may reduce currency risk. }\end{array}$ & $\checkmark$ & & $\checkmark$ \\
\hline & World Bank Backed Project & Multilateral-Backed loan facility & $\checkmark$ & $\checkmark$ & \\
\hline & Not Provided/Negotiated & "Preferred Creditor status" to the MLA & & $\checkmark$ & $\checkmark$ \\
\hline & $\begin{array}{l}\text { Sponsor to be responsible for obtaining necessary permit } \\
\text { and approval }\end{array}$ & $\begin{array}{l}\text { Existence of operational permit and approval from the } \\
\text { public sector }\end{array}$ & & $\checkmark$ & $\checkmark$ \\
\hline
\end{tabular}


of

Risk Factors (RF)

Risk Mitigation Strategies Proffered by Project Sponsors

\section{Lenders Bankability Criteria for Project Appraisal}

\begin{tabular}{|c|c|c|}
$\begin{array}{c}\text { Case Study } \\
\text { A }\end{array}$ & $\begin{array}{c}\text { Case } \\
\text { Study B }\end{array}$ & $\begin{array}{c}\text { Case } \\
\text { Study } \\
\text { C }\end{array}$ \\
\hline Focus Group & Focus Group & Focus \\
\hline $\mathbf{( 1 )}$ & $\mathbf{( 1 )}$ & $\mathbf{( 1 )}$ \\
\hline
\end{tabular}

\begin{tabular}{|c|c|c|c|c|c|}
\hline \multirow{4}{*}{ Legal Risk } & Pre-construction environmental impact assessment & Social and Environmental Due diligence & $\checkmark$ & $\checkmark$ & $\checkmark$ \\
\hline & Compliance with Equator Principles & Compliance with Equator Principles & $\checkmark$ & $\checkmark$ & $\checkmark$ \\
\hline & Sponsors to bear legal risk & Legal Risk to be borne by sponsor & $\checkmark$ & $\checkmark$ & $\checkmark$ \\
\hline & Not provided & Annual Reporting of EP's application & & $\checkmark$ & \\
\hline \multirow{7}{*}{ Concession Risk } & Concession risk to be borne by project sponsors & Concession risk to be transferred to the SPV & $\checkmark$ & $\checkmark$ & \\
\hline & $\begin{array}{l}\text { Risks arising from performance failure deductions will be } \\
\text { transferred to O\&M contractor }\end{array}$ & O\&M contractor to bear performance failure risks & $\checkmark$ & $\checkmark$ & $\checkmark$ \\
\hline & Project Grantor identified and has capacity for approvals & Identity of Grantor and its approval capacity must be known & $\checkmark$ & $\checkmark$ & $\checkmark$ \\
\hline & Not Provided/Negotiated & $\begin{array}{l}\text { Direct Agreement with project grantor and other project } \\
\text { contractors and sub-contractors }\end{array}$ & & $\checkmark$ & \\
\hline & Not Provided/Negotiated & $\begin{array}{l}\text { Debt repayments to terminate one or two years before the } \\
\text { exnirv of concession contract }\end{array}$ & $\checkmark$ & $\checkmark$ & \\
\hline & Not Provided/Negotiated & $\begin{array}{l}\text { Security rights over SPV's insurance policies, Cash flows } \\
\text { and other corresponding assets. }\end{array}$ & $\checkmark$ & $\checkmark$ & $\checkmark$ \\
\hline & Not Provided/Negotiated & Right of lenders to replace O\&M Contractor & $\checkmark$ & $\checkmark$ & $\checkmark$ \\
\hline
\end{tabular}

Based on evidences from the study "More Advantage" indicates that the corresponding risk mitigation strategy proposed by the sponsors were not essential but offer more advantage to lenders.

"Not Provided/Negotiated" indicates that project sponsors did not provide the required bankability criteria from lenders, but rather negotiated such criteria with by offering other mitigations. 


\section{Reliability Analysis}

347 Since one of the major objectives of this study is to confirm the wider applicability of the

348 various bankability criteria unravelled through the qualitative study, statistical analysis of the

349 questionnaire survey to financiers was carried out. As argued by many social scientists

350 (Spector, 1992; Field, 2005; Santos, 1999), when using Likert Scale questionnaire, a

351 Cronbach's alpha coefficient of reliability must be calculated. Reliability analysis facilitates

352 validity and wider applicability of the bankability criteria, while ensuring the criteria

353 represents true measures of the construct (bankability of the four major risks in PPP loan

354 application from an emerging market). Cronbach's Alpha is mathematically written as:

$$
\alpha=\frac{N^{2} \overline{C O V}}{\sum_{\text {factor }}^{S^{2}}+\sum C O V_{\text {factor }}}
$$

355 Where $\mathrm{N}=$ the total number of criteria; $\mathrm{COV}=$ average covariance between criteria; $\mathrm{S}_{\text {factor }}=$ 356 variance of each criterion; and COV factor = covariance within a criterion. Since the rule of 357 thumb in Cronbach's alpha coefficient is usually between 0 and 1; a value of 0.7 was 358 considered acceptable (George and Mallery, 2003), while a value of 0.8 suggests strong 359 internal consistency. Using the Statistical Package for Social Sciences (SPSS) software tool, 360 the Cronbach's alpha coefficient for this study was 0.745 (see Table 4 for Reliability Analysis 361 results). This demonstrated good internal consistency and reliability of most of the 362 bankability criteria. Additionally, in order to ascertain whether all the bankability criteria are 363 truly contributing to internal consistency of the construct, the fifth column of Table 4 labelled 364 “Cronbach's alpha if item deleted” was examined. According to George and Mallery (2003), 365 any criterion that is not contributing to the overall reliability of the data, will have its 366 Cronbach's alpha coefficient higher than the overall coefficient $(0.745)$. 
Table 4: Reliability Analysis and Significance Ranking of Bankability Criteria

\begin{tabular}{|c|c|c|c|c|c|c|c|}
\hline $\begin{array}{l}\text { Risk } \\
\text { Factors } \\
\text { (RF) }\end{array}$ & & $\begin{array}{c}\text { Lenders Bankability Criteria for Evaluating PFI/PPP Loan } \\
\text { Application in an Emerging Market Project }\end{array}$ & $\begin{array}{l}\text { Corrected } \\
\text { Items: } \\
\text { total } \\
\text { correlation }\end{array}$ & $\begin{array}{l}\text { Cronbach's } \\
\alpha \text { if items } \\
\text { deleted }\end{array}$ & $\begin{array}{l}\text { Significance } \\
\text { Index }(\%)\end{array}$ & $\begin{array}{l}\text { Ranking } \\
\text { within } \\
\text { Group }\end{array}$ & $\begin{array}{c}\text { Overall } \\
\text { Ranking }\end{array}$ \\
\hline \multirow{6}{*}{ Sponsor Risk } & $\mathrm{BC} 1$ & $\begin{array}{l}\text { Sponsors with track record of successful project financing, strong credit quality } \\
\text { and financial capacity }\end{array}$ & 0.608 & 0.721 & 85.10 & 1 & 4 \\
\hline & $\mathrm{BC} 2$ & Bank-financed guarantee facility or Pre-completion guarantee & 0.308 & 0.736 & 84.11 & 2 & 10 \\
\hline & $\mathrm{BC} 3$ & Mix of management skills and experience demonstrated by or available to sponsors & 0.544 & 0.719 & 69.10 & 5 & 18 \\
\hline & $\mathrm{BC} 4$ & Sponsor with well-established relationship with a lender & 0.512 & 0.718 & 70.23 & 4 & 17 \\
\hline & $\mathrm{BC} 5$ & Satisfactory equity contribution by the sponsors & 0.450 & 0.730 & 84.03 & 3 & 11 \\
\hline & BC6 & Equity contribution must be available either in cash or in a blocked account & 0.568 & 0.727 & 55.65 & 6 & 20 \\
\hline \multirow{5}{*}{ Political Risk } & $\mathrm{BC} 7$ & Full Transfer of political risk to export credit agency (ECA) & 0.333 & 0.736 & 85.32 & 1 & 1 \\
\hline & $\mathrm{BC} 8$ & Country capacity/political risk insurance from private sector insurer & 0.310 & 0.737 & 76.41 & 4 & 14 \\
\hline & BC9 & $\begin{array}{l}\text { Raising part of the project loan from indigenous banks in project host nation to reduce } \\
\text { currency risk }\end{array}$ & 0.510 & 0.738 & 59.01 & 5 & 19 \\
\hline & $\mathrm{BC} 10$ & Multilateral Agency-Backed Loan facility & 0.377 & 0.720 & 85.21 & 2 & 2 \\
\hline & $\mathrm{BC} 11$ & "Preferred Creditor Status" granted by the MLA to participating banks & 0.359 & 0.738 & 81.15 & 3 & 12 \\
\hline \multirow{4}{*}{ Legal Risk } & $\mathrm{BC} 12$ & Existence of Operational permit and approval from the project grantor & 0.314 & 0.733 & 85.01 & 1 & 5 \\
\hline & $\mathrm{BC} 13$ & Social and environmental due diligence & 0.378 & 0.740 & 84.43 & 2 & 8 \\
\hline & $\mathrm{BC} 14$ & Compliance with Equator Principles & 0.388 & 0.746 & 84.15 & 3 & 9 \\
\hline & $\mathrm{BC} 15$ & Annual reporting of Equator Principles implementation on the project & $0.114 *$ & $0.820 *$ & 51.24 & 4 & 22 \\
\hline & & & 4 & & & & \\
\hline \multirow{7}{*}{$\begin{array}{c}\text { Concession } \\
\text { Risk }\end{array}$} & $\mathrm{BC} 16$ & Concession risk to be transferred to the project company & 0.484 & 0.725 & 72.15 & 5 & 15 \\
\hline & $\mathrm{BC} 17$ & $\begin{array}{l}\text { Direct contractual relationship between lenders and project grantor, as well as } \\
\text { other project contractors and sub-contractors respectively }\end{array}$ & 0.529 & 0.721 & 84.70 & 2 & 6 \\
\hline & $\mathrm{BC} 18$ & $\begin{array}{l}\text { Security rights over project company's insurance policies, cash flows and other } \\
\text { income generating contracts as well as assets }\end{array}$ & 0.540 & 0.723 & 84.49 & 3 & 7 \\
\hline & BC19 & Identity of project grantor and her approval capacity must be ascertained & 0.507 & 0.726 & 85.12 & 1 & 3 \\
\hline & $\mathrm{BC} 20$ & Debt repayments to terminate one or two years before the expiration of concession & $0.217 *$ & 0.771* & 54.11 & 7 & 21 \\
\hline & $\mathrm{BC} 21$ & Right of lenders to replace operations and maintenance contractor & 0.554 & 0.745 & 71.04 & 6 & 16 \\
\hline & $\mathrm{BC} 22$ & Operations and Maintenance contractor to bear performance failure risks & 0.388 & 0.718 & 79.17 & 4 & 13 \\
\hline
\end{tabular}




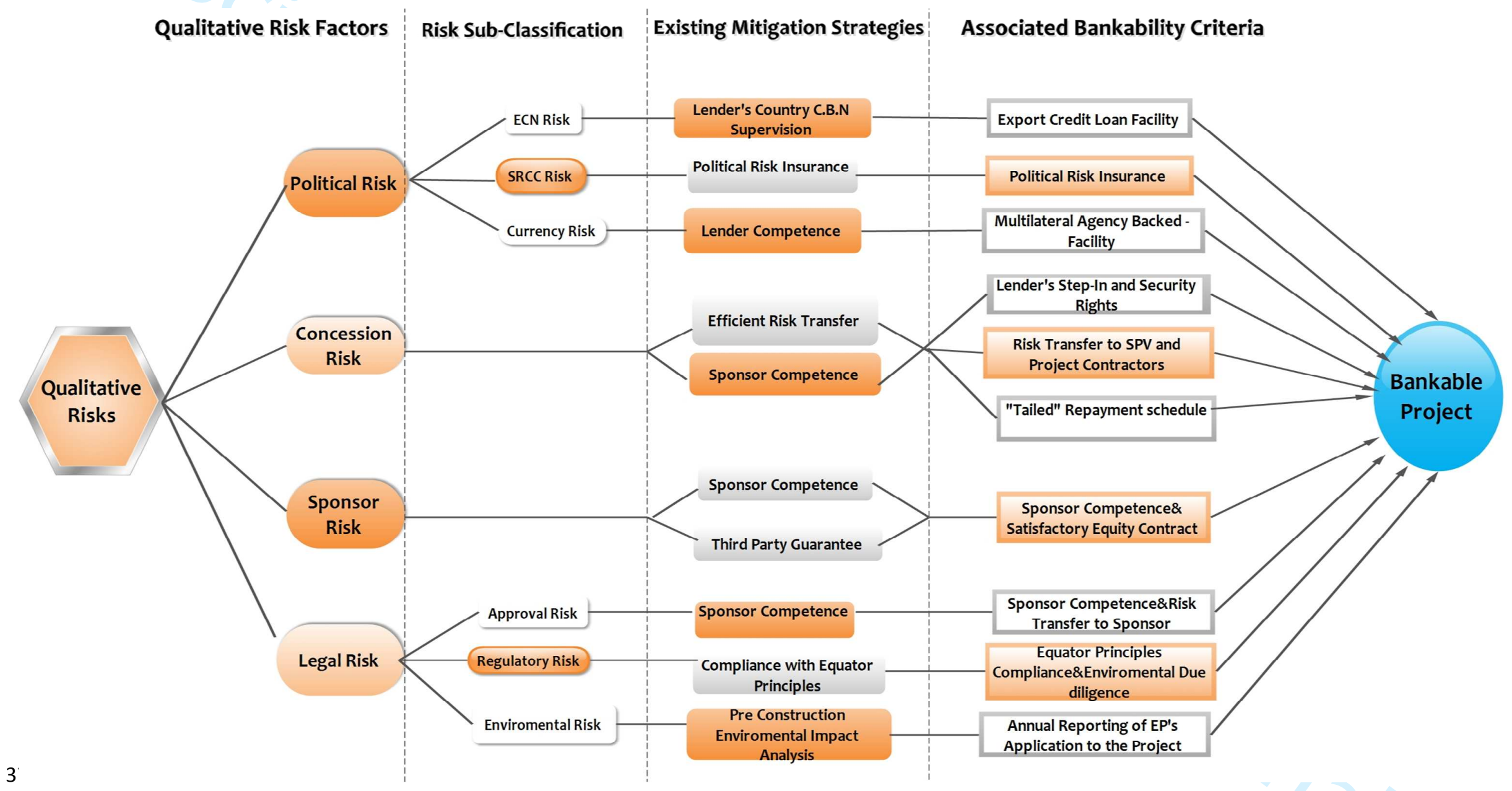


375 This suggests that such higher value for a criterion, if deleted, would improve the overall reliability 376 of the entire data set (Field, 2005). Based on this rule, only two criteria (BC15 and BC20) were 377 revealed to have values of 0.820 and 0.771 respectively as reflected in the fifth column of Table 8 . 378 This indicates that the criteria - "Annual reporting of Equator principles in project host nation" and 379 "Debt repayments to terminate one or two years before the expiry of concession contract " are 380 considered unreliable and do not represent a good measure of evaluating bankability of legal and 381 concession risks. This also corresponds with the low correlation coefficient of these two criteria, as 382 shown in the fourth column of Table 8. The Correlated item: total correlation column represents the 383 correlation between each criterion and Cronbach's alpha $(\alpha)$ of the entire data. In reliable data, all 384 criteria are expected to correlate with the overall reliability. As such, any correlation coefficient that 385 is less than 0.3 should be dropped (Santos, 1999). In view of this, the two bankability criteria BC15 386 and $\mathrm{BC} 20$ show correlation coefficient of 0.237 and 0.117 respectively. As such, these two criteria 387 were later dropped from the list, leaving us with only 20 reliable bankability criteria.

\section{Significance Index Ranking}

389 After conducting reliability and correlation analysis, this study proceeded to identify the significance 390 index ranking of each criterion based on lenders' perception. Significance indexing is a quantitative 391 technique, which ranks all criteria from the survey based on their relative significance value. Similar 392 to the approached used by Spillane et al. (2012) and Tam et al. (2000), the significance index ratings 393 for the 22 criteria were arrived at using a simple mathematical equation expressed below:

$$
\text { Significance Index }(S I)=\left(\frac{\sum(s)}{N S}\right) \times 100 \%
$$

394 Where s represents the significance rating on a Likert scale of 1 to $5, \mathrm{~S}$ is the highest significance 395 rating (that is 5) and $\mathrm{N}$ is the total number of responses for that particular criteria. The significance 396 index and ranking are shown in column six, seven and eight of Table 8 respectively. With 
397 significance index calculation, the linear five-point Likert scale used in the questionnaire is 398 converted into a percentage scale. As such, 0\% represents the lowest, while $100 \%$ represents the 399 highest significance value achievable. This indicated that the Likert scale values of 1, 2, 3, 4, and 5 400 have significance indexes of $0,25,50,75$, and 100, respectively. Based on the survey analysis, 401 significance index (SI) values were produced for the 22 bankability criteria ranging from 85.32 to 40251.24 (see Table 8 for bankability criteria's significance index ranking). The top seven most 403 significant bankability criteria with an overall index ranking of moderately significant or SI value of $404 \geq 75.00$ across the four country-specific risks are:

405

\subsection{Discussion of Findings}

417 This section discusses findings from focus group discussions and questionnaire survey to foreign 418 project financiers and experts concerning bankability of country-specific risks (Sponsor, political, 419 Legal and concession risks) in PPP loan applications in an emerging market. Twenty (20) important 420 bankability criteria for evaluating the four risks were explored from foreign financiers' perspectives. 
421 The significance ranking of each criterion towards determining the bankability of country-specific

422 risks in PPP loan applications was calculated. Evidences from the questionnaire survey, as shown in

423 Table 4 above, were corroborated with findings from the focus group discussions with financiers

424 (See Table 3 and 4). Results from the study were used to construct a "Risk and Bankability

425 Framework" and validated with new data set from project financiers (see Fig.2. for Risk and

426 Bankability Framework).

\section{6.1. Sponsor Risk and Associated Bankability Criteria}

428 Evidences from the study, as reflected in Table 3, revealed sponsor risk is inherent in the three PPP 429 case studies investigated. Focus Group Discussion (FGD) participants referred to sponsor risk 430 analysis as a "smell test" that must be conducted by lenders before loans are granted. In evaluating 431 sponsor risk in PPP loan applications within emerging market context, lenders consider the 432 "competence of the project sponsors" to be crucial to bankability. This is based on results from the 433 questionnaire survey, which shows a high significance index ranking of 85.10 , in terms of its 434 influence on bankability of sponsor risk (see Table 4). The result confirms findings from the FGD 435 captured in the views of one of the participants who argued that:

“Foreign lenders will consider factors like sponsor's identity, sponsors' credit background, the sponsor's financial strength, the sponsor's history of corporate dealings, probability of default etc."

439 The above assertions highlights Atmo and Duffield (2014) as well as Hoffman (2008) who argue that 440 the fact that project finance loans are granted to a newly formed Special Purpose Vehicle (SPV) does 441 not suggest lenders are not interested in the identity and credit history of project sponsors. Rather, the 442 profile of the project sponsors or any prior banking relationship with the lender will play a crucial 443 role in addressing possible information asymmetry. Another important bankability criterion for 444 evaluating sponsor risk, based on results from the survey, is the "existence of Pre-completion 
445 guarantee or full-financial guarantee presented by project sponsors". Evidences in Table 4 show 446 a significance index ranking of 84.11, indicating high lenders' perception of the criterion towards 447 influencing lenders bankability decision. The result buttresses suggestions from some of the FGD 448 participants who argued that, where lenders are not satisfied with the credit risk profile of a project 449 sponsor: guarantee, for better considerations."

"In such cases a foreign bank will demand credit risk enhancements such as Pre-completion Guarantee, full-financial Guarantee, third party guarantee or even a bank-financed

This is in line with Hoffman (2008) and Mills (2010) who opined that, to foreign lenders, credit guarantee serves as collateral against project incompletion. Hence, the presence of such facilities in a 455 PPP loan application will improve the bankability of such funding applications from foreign 456 financiers' perspectives (Grimsey and Lewis, 2002). According to Yescombe (2007) and Mills 457 (2010), credit risk enhancement may become crucial to lenders where the sponsors have weak credit 458 quality or have no prior experience in project financing arrangements. In addition, going by findings 459 revealed in Table 3, another crucial bankability criterion used for evaluating sponsor risk in PPP loan 460 applications from an emerging market is the "sponsors' equity case". Relying on survey findings 461 which show a significance ranking of 84.03 for this criterion (see Table 4), the share of equity 462 contribution of projects sponsors must be satisfactory to lenders. As confirmed by FGD findings, 463 participants' argue that:

464 "It is also important to consider the debt equity ratio on offer. This is because; the amount of equity to be injected into the project by the sponsor team and the timing of such injection will also influence foreign funding decision”.

467 Studies such as Demirag et al. (2011), Al-Khattab et al. (2007) and Mills (2010) have confirmed the 468 above claim and argued that the amount of equity contribution of sponsors will determine the extent 469 of the lenders' funding, her recourse as well as the loan price during due diligence appraisal. 
470 According to Hoffman (2008), lenders believe that, the more the sponsor's equity at stake in PPP

471 projects, the higher the commitment and the lesser the possibility of walking away in case the project

472 encounters challenges.

$473 \quad$ 6.2 Country/Political Risk and Associated Bankability Criteria

474 Going by evidences from the study, political risk was considered very important in the three PPP 475 projects' case studies investigated. As shown in the results from the questionnaire survey (see Table 4763 and 4), an important bankability criterion for evaluating political risk in PPP loan applications is 477 the "transfer of political risk to Export credit agencies". The high significance ranking of the 478 criterion (85.32) confirms lenders' strong perception of its influence on the bankability of political 479 risk in PPPs, especially from an emerging market context (see Table 4). This perspective was also 480 highlighted by discussants in some of the focus group discussions.

“Definitely, Export Credit Agency (ECA) assisted facility has got high bankability potentials. Foreign Banks can be sure their political risk exposure is covered to a significant level”.

483 In buttressing the above perspective, Matsukawa and Habeck (2007) argued that, ECAs are 484 providing a new source of long-term finance for infrastructures especially in the emerging BRICs 485 nations. This helps reduce cost of lending to critical infrastructures, while international lenders are 486 able to transfer political risks in projects to the public financial agencies. However, according to 487 Giannetti and Ongena (2012), in practice, ECAs do not provide "Full Risk Transfer" to lenders 488 because certain percentage of the project loan (5\%-10\%) is usually uncovered under the ECAs' 489 political risk guarantee. In addition, going by findings from the survey as well as the focus group 490 discussions, the involvement of "Multilateral Agencies (MLA)" such as the World Bank usually 491 enhances the potentials of indigenous investors' loan applications. Evidences from the survey 492 revealed high lenders perception with a significance index of 85.21, concerning the important role of 
493 MLAs in providing political risk cover for PPPs in emerging markets. This buttressed the 494 perspectives of many FGD participants, who opined that:

\section{5}

“Many PPP projects in these (developing) economies are often World Bank and IFC (International Finance Corporation) assisted....especially Africa .... And that's good for us as an international lender since it provides much guarantee against the common political risk situations in many of

499 This view has been confirmed by Hoffman (2008) and Ramamurti (2009) who suggested that MLAs 500 provide some form of political risk guarantees for participating banks in order to encourage 501 financing. This is evidenced by the "Preferred Creditor's Status" usually granted banks collaborating 502 with MLAs in financing a project. Such involvement of international development financier boosts 503 the bankability consideration of a prospective PPP project (Delmon, 2011). Further findings from 504 FGD participants as reflected in Fig. 4 above, identified three sub-risk components, which often 505 spinout from political risk and are thus inter-dependent:

514 showing a significance index rating of 76.41, indicating high lenders' perception. In what seemed

515 largely a unanimous opinion, most FGD participants emphasized the importance of private-sector 
516 political risk insurance in financing PPPs in emerging market. As captured in the view of one of the 517 participants:

518 "If foreign Banks were to finance such projects, depending on the country capacity of the project 519 host nation, we would definitely request a Private-Sector Political Risk Insurance Cover from would520 be project sponsors. This is one of the most common global best practices in international lending to 521 projects. It does not have to be a PPP project before banks consider political risk insurance cover".

522 Studies such as Hoffman (2008), Yescombe (2007), Atmo, and Duffield (2014) have confirmed these 523 assertions. According to Yescombe (2007)and Hoffman (2008), private-sector political risk 524 insurance cover may be in form of general insurance cover for a PPP project; or may be tailored to 525 the foreign lenders' key concerns (Delmon, 2011). In situations where the insurance policy is 526 targeted at lenders' specific concerns in the concession, any risk arising from events not mentioned 527 in the insurance policy will not be reimbursed (Mills, 2010).

\section{$528 \quad 6.3 \quad$ Legal Risk and Associated Bankability Criteria}

529 Going by evidences from the study, legal risk was important and was given high consideration by 530 financiers in the three case studies examined. As represented in the qualitative framework in Figure 2 531 above, the study identified three sub-risk factors that often emerge from legal risk: permit and 532 approval risk, regulatory risk and environmental risk. Based on evidences from the survey, the 533 bankability criterion "existence of operational permit and approval from public sector" is 534 considered most important in legal risk analysis. This is based on lenders' perception with a 535 significance index rating of 85.01. Focus group discussants also highlighted the importance of 536 permit and approval to successful implementation of PPPs, as encapsulated in the views of one of the 537 discussants who argued that:

538 "One needs to determine whether such proposed project has got necessary permits and 539 approval from relevant government departments or agencies. Foreign banks will expect 
sponsors of projects to obtain legal and regulatory approvals for the construction and

operations of a project. Of course failure to obtain such results in delay in project start-up

543 This view was buttressed by Wang et al. (2004) who argued that project grantor's approval is 544 essential to funding decision because most financiers will not fund any unapproved concession. As 545 such, sponsors are usually expected to present lenders with operational permits and approvals of 546 project, as a condition for funding approval. Additionally, in evaluating potential legal risks in a PPP 547 loan application from an emerging market context, results from questionnaire survey show that, 548 foreign lenders consider the "environmental impact assessment of potential projects" on host 549 communities, as very crucial to loan approval. This confirms the high significance index of the 550 criterion at 84.43 , based on lenders perception. In supporting the above perspective, many 551 discussants in the focus groups opined that:

"International lenders will request project sponsors to present evidence of Environmental Impact Assessment (EIA) report of the project. The EIA report details the potential impact of the project on the host community. It's important for banks to avoid litigation arising from environmental damage to a project host community as this portends great danger to lenders funds".

556 The above perspective is buttressed by Hoffman (2008), who suggested that, lenders are increasingly 557 becoming more environmentally aware of impacts of projects on host communities. As such, most 558 banks will seek to avoid a reputational risk that may arise due to negative publicity from 559 environmental pressure groups (Mills, 2010). This is more essential, especially where the project 560 host nations are outside the OECD nations and external risks to projects is often high (Yescombe, 561 2007). Further results from the survey also show a high significance index rating of 84.15 for 562 "Compliance with Equator Principles". The significance index of the criterion confirms evidences 563 from focus group discussions, as captured in the views of one of the discussants who argued that: 
“We would have to also consider the project's Compliance with Equator Principles (EPS). These equator principles are World Bank's global environmental best practices, and most international lenders in OECD nations will request this as part of due diligence appraisal for funding approval.".

567 Existing literatures such as Amalric (2005), Gupta et al. (2002), Yescombe (2007), share this 568 perspectives and argued that, a common practice for most compliant banks in OECD nations is, to 569 insist on environmental impact assessment of proposed PPP projects. This is in line with global 570 environmental KPIs' as prescribed by the Equator Principles (Gupta et al., 2002). Equator Principles 571 (EPs) was introduced in 2003 in Washington DC after a consultation among select international 572 lenders and the International Finance Corporation (IFC) (Hardenbrook, 2007). With the EPs, key 573 Performance standards in terms of socio-environmental sustainability of project's geographical 574 location were introduced in line with the World Bank health and Safety general guidelines (Giannetti 575 and Ongena, 2012).

\subsection{Concession Risk and Associated Bankability Criteria}

577 As represented in Table 3 above, evidences from the study indicate that, the lenders examined 578 concession risk when evaluating the three case studies under investigation. Based on results from 579 survey responses with respect to determining the bankability of concession risk in PPP loan 580 application within emerging market context (see Table 4), top on lenders' criteria is unravelling the "identity and powers of the project grantor". This is evidenced by the significance index rating of

58285.12 from survey analysis. FGD participants also share these perspectives, and this was captured in 583 the view of a discussant who argued that:

584 "The identity of the Awarding Authority (project grantor) coupled with her capacity to 585 grant concession approvals will be critically assessed before foreign banks commit funds to such PPP project”'. 
587 This perspective is in line with Mills (2010) and Delmon (2011) who argued that a project grantor 588 must have the legal powers to contract a project on concession basis. The lack of such powers 589 therefore, automatically invalidates the actions of the awarding authority and poses threats to the 590 realization of the project. Giannetti and Ongena (2012) suggested that foreign lenders want to 591 ascertain whether a project grantor enjoys implicit cooperation and supports of higher authorities in 592 the project's host nation for her contractual activities. This enables lenders to envisage any potential 593 clash of interests between the provisions of the concession and existing government laws in host 594 nations (Sachs et al., 2007). Additionally, further evidences from the survey as shown in Table 4 595 revealed that, asides unravelling the identity and powers of the project grantor, foreign lenders 596 considering emerging market PPP loan applications will also require "direct legal contracts with 597 the project grantor and other parties to the project”. Based on significance index rating of 84.70, 598 survey respondents consider this criterion important in evaluating concession related risks in an 599 emerging market. This further attest to evidences from the qualitative study in which some focus 600 group participants opined that: project sub-contractors in an emerging market PPP project. Obviously such agreements is to enable lenders protect her Secured Creditor's Rights with the authority, in case the concession is terminated".

605 The above assertion is in line with Busse and Hefeker (2007) and Chan et al. (2014), who both 606 argued that lender's direct agreements ensures that the contractual relationship between the SPV and 607 other sub-contractors are in tandem with clauses and service level specifications stipulated in the 608 concession contract. Such direct contract therefore puts lenders in the supervisory role, especially 609 considering the high-leverage nature of PPPs and relative systemic instability in many of these 610 regions. 
611 Further findings from the study also indicate that, as part of measures to ensure proper due diligence 612 is taken on funding applications for PPPs in an emerging market; "lenders will impose some 613 security rights on the project SPV". Based on survey responses, the significance index rating of 614 this criterion is 84.49. This suggest high lenders' perception with respect to its influence on 615 bankability of concession risk. The above evidence further confirms perspectives highlighted during 616 some of the FGDs. As encapsulated in the argument of one of the discussants:

"You have to demand contractual security rights on PPP project assets, cash flows and other income generating contracts of the SPV. These are very important issues in bankability for most lenders to PPPs".

620 Boeing and Kalidindi (2009) highlighted the above perspective and suggested that, in most instances

621 lenders exercise security rights over assets and cash flows of PPPs in order to consolidate their 622 positions in a project. This becomes more important in the event of project failure or concession 623 termination by the awarding authority. Hence, such security rights help foreign lenders to mitigate 624 the severity of any exposure at project default (Hoffman, 2008).

\section{$625 \quad 7.0$ Conclusion}

626 Project finance stakeholders consider the bankability of country-related risks as essential for funding

627 PPP projects in emerging markets. Bankability of project risk is even more crucial within Sub

628 Saharan African context given the high country-risk perception which has hindered adequate foreign

629 financing. This study embraced a mixed methodology approach to investigate four country-related

630 risks prevalent in many emerging markets by using Nigerian PPP environment as context. The

631 investigated risks included sponsor risk, political, legal and concession risks. Multiple case studies of

632 three PPP projects in Nigeria were used to identify important bankability criteria for evaluating

633 project loan applications within emerging market context. The qualitative strategy comprise focus 
634 group discussions (FGD) with foreign financiers in Nigeria's existing PPPs, and loan document

635 analysis which helped reveal 22 relevant bankability criteria. Going further the wider acceptability of

636 the 22 bankability criteria were later confirmed using a questionnaire survey to wider audiences

637 among foreign and local financiers in Nigeria's PPP market. Statistical results of the survey revealed

638 top seven (7) bankability criteria considered "very important" for winning foreign financiers' loan

639 approval for PPPs in emerging market. These include: BC7= Full Transfer of Political Risk to Export

640 Credit Agency (ECA), BC10= Multilateral Agency-Backed Loan Facility, BC19= Identity of project

641 grantor and her approval capacity must be known., BC1= Sponsors with track record of successful

642 project financing, strong credit quality and financial capacity, $\mathrm{BC} 12=$ Existence of operational permit

643 and approval from the project grantor, $\mathrm{BC} 17=$ Direct contractual agreement between lenders and

644 project grantor, as well as other project contractors and sub-contractors respectively, and $\mathrm{BC} 18=$

645 Security rights over SPV's insurance policies, cash flows and other corresponding assets. Further

646 findings from the study also revealed the complexity and true structure of certain risks in emerging

647 markets PPPs, with the existence of sub-risk components (i.e. ECN, SRCC Currency, approval,

648 environmental risk, approval risk, etc.). It is relevant to note that, most sub-risk components PPP

649 evaluation often come as offshoots of many major risk factors during analysis. Hence, the occurrence

650 of the major risks will automatically throw up other emerging risk components which require equal

651 and careful bankability evaluation. Results from this study confirm a number of existing studies by

652 arguing that, unless risks are matched with their bankability criteria and practical mitigation, the

653 much needed clarity will be lacking especially in market where PPP growth is still nascent. Based on

654 findings from the study a "Risk and bankability framework model" for assessing the four country-

655 specific risks in PPP loan applications within an emerging market context was developed. The

656 framework model pairs risk factors with various mitigation strategies as well as associated

657 bankability criteria under a single platform. The study validated the model with another set of data

658 from foreign project financiers and other subject matter experts with emerging market project 
659 financing experiences. As such, the framework model proposed in the study presents a valuable

660 mind-map tool and checklist for foreign financiers including private investors interested in emerging

661 market PPP projects. This result mirrors the perspective of Kayaga (2008), who suggested that the

662 relative slow pace of PPP growth in Sub Saharan Africa can be attributed to huge hindrance posed by

663 country-related risks to the bankability of indigenous PPP projects. Thus, results from the study

664 represent critical parameters for winning foreign loan approval for PPP infrastructure projects within

665 an emerging market context.

666

667 Future studies should endeavour to widen the scope of this study. These include using more contexts

668 to confirm the applicability of findings from the current study with respect to other emerging

669 economies. It may also be very essential to explore the impact of public sector guarantee on the

670 bankability of PPPs within emerging market context. Further empirical studies are also needed on

671 how to avoid lenders' "call for event of default" in PPP projects, determinants of sponsors' equity

672 contribution in typical project finance arrangements, and lenders' perspective to securitization in PPP

673 projects among other things. 


\subsection{References}

676

677

678

679

680

681

682

683

684

685

686

687

688

689

690

691

692

693

694

695

696

697

698

699

700

701

702

703

704

705

706

707

708

709

Akintoye, A., Beck, M., \& Kumaraswamy, M. (Eds.). (2015). Public private partnerships: A global review. Routledge.

Al Khattab, A., Anchor, J., \& Davies, E. (2007). Managerial Perceptions of Political Risk in International Projects. International Journal of Project Management, 25(7), 734-743.

Amalric, F. (2005). The Equator Principles: A Step towards Sustainability. [Online]. Center for Corporate Responsibility and Sustainability. [Accessed $3^{\text {rd }}$ Feb, 2015].

Ameyaw, E. E., \& Chan, A. P. (2015). Evaluation and ranking of risk factors in public-private partnership water supply projects in developing countries using fuzzy synthetic evaluation approach. Expert Systems with Applications, 42(12), 5102-5116.

Atmo, G. U., and Duffield, C. (2014). Improving Investment Sustainability for PPP Power Projects in Emerging Economies: Value for Money Framework. Built Environment Project and Asset Management, 4(4).

Babatunde, S. O., \& Perera, S. (2017). Barriers to bond financing for public-private partnership infrastructure projects in emerging markets: A case of Nigeria. Journal of Financial Management of Property and Construction, 22(1), 2-19.

Babatunde, S. O., Opawole, A., and Akinsiku, O. E. (2012). Critical Success Factors in PublicPrivate Partnership (PPP) on Infrastructure Delivery in Nigeria. Journal of Facilities Management, 10(3), 212-225.

Basilio, M. (2011). Infrastructure PPP investments in Emerging Markets. [Online]. Available at [http://www.efmaefm.org/0EFMAMEETINGS/EFMA\%20ANNUAL\%20MEETINGS/2011Braga/papers/0337_update.pdf]. [Accessed on 12 ${ }^{\text {th }}$ Feb, 2015].

Bekaert, G. and Harvey, C. R. (2002). Research in Emerging Markets Finance: Looking to the Future. Emerging Markets Review, 3(4), 429-448.

Bing, L., Akintoye, A., Edwards, P. J. and Hardcastle, C. (2005). The Allocation of Risk in PPP/PFI Construction Projects in the UK. International Journal of project management, 23(1), 25-35.

Briceño-Garmendia, C., Smits, K., and Foster, V. (2008). Financing Public Infrastructure in SubSaharan Africa: Patterns and Emerging issues. AICD Background Paper, 15(1).

Boeing Singh, L. and Kalidindi, S. N. (2009). Criteria Influencing Debt Financing of Indian PPP road projects: A Case Study. Journal of Financial Management of Property and Construction, $14(1), 34-60$

Busse, M. and Hefeker, C. (2007). Political Risk, Institutions and Foreign Direct Investment. European journal of political economy, 23(2), 397-415.

Cavusgil, S. T. (1997). Measuring the Potential of Emerging Markets: An Indexing Approach. Business Horizons, 40(1), 87-91. 
Chan, A. P., Lam, P. T., Wen, Y., Ameyaw, E. E., Wang, S. and Ke, Y. (2014). Cross-Sectional Analysis of Critical Risk Factors for PPP Water Projects in China. Journal of Infrastructure Systems.

Creswell, J. W. (2013). Research design: Qualitative, Quantitative, and Mixed Methods Approaches. Sage Publications.

Coviello, N. E., and Jones, M. V. (2004). Methodological Issues in International Entrepreneurship Research. Journal of Business Venturing, 19(4), 485-508.

Delmon, J., (2011). Public-Private Partnership Projects in Infrastructure: An Essential Guide for Policy Makers. New York: Cambridge university press.

Demirag, I., Khadaroo, I., Stapleton, P., and Stevenson, C., (2011). Risks and the Financing of PPP: Perspectives from the Financiers. The British Accounting Review, 43 (2011) 294-310.

Dominic, M. U., Ezeabasili, A. C. C., Okoro, B. U., Dim, N. U., \& Chikezie, G. C. (2015). A review of Public Private Partnership on some development projects in Nigeria. International Journal of Application Innovation in Engineering \& Management, 4(3).

Eaton, D., Akbiyikli, R. and Dickinson, M. (2006). An Evaluation of the Stimulants and Impediments to Innovation within PFI/PPP projects. Construction Innovation: Information, Process, Management, 6(2), 63-67.

Feagin, J. R., Orum, A. M., and Sjoberg, G. (Eds.). (1991). A case for the case study. UNC Press Books.

Field, A. (2005). Discovering Statistics using SPSS. 2nd Ed., Sage Publications, London.

George, D. and Mallery, M., (2003). Using SPSS for Windows Step-by-Step: A Simple Guide and Reference. Boston, MA: Allyn y Bacon.

Giannetti, M. and Ongena, S. (2012). "Lending by Example": Direct and Indirect Effects of Foreign Banks in Emerging Markets. Journal of International Economics, 86(1), 167-180.

Grimsey, D., and Lewis, M., (2002). "Evaluating the Risks on Public Private Partnerships for Infrastructure Projects". International Journal of Project Management, Vol. 20, pp 107-118.

Gupta, P., Lamech, R., Mazhar, F. and Wright, J. (2002). Mitigating Regulatory Risk for Distribution Privatization: The World Bank Partial Risk Guarantee. Energy \& Mining Sector Board Discussion Paper. Series, (5).

Gutman, J., Sy, A., \& Chattopadhyay, S. (2015). Financing African infrastructure: Can the world deliver?.

Hammami, M., Ruhashyankiko, J. F. and Yehoue, E. B. (2006). Determinants of public-private partnerships in infrastructure. [Online]. International Monetary Fund. Available at [https://www.imf.org/external/pubs/ft/wp/2006/wp0699.pdf]. [Accessed on $16^{\text {th }}$ Feb, 2015].

Hardcastle, C., Edwards, P. J., Akintoye, A. and Li, B. (2005). Critical Success Factors for PPP/PFI Projects in the UK Construction Industry: A Factor Analysis Approach. Construction Management and Economics, 23(5), 459-471. 
Hoffman, S.L., (2008). The Law and Business of International Project Finance, 3rd edition. New York: Cambridge University press.

Ibem, E. O. (2010). An Assessment of the Role of Government Agencies in Public-Private Partnerships in Housing Delivery in Nigeria. Journal of Construction in Developing Countries, 15(2), 23-48.

International Finance Corporation Report (2013). Advisory Services in Public Private Partnerships in Sub Saharan Africar Available online [www.ifc.org/wps/wcm/connect/.../RegionalFactsheet_Africa.pdf?MOD..]. [Accessed on $3^{\text {rd }}$ Jan, 2015].

Kayaga, S., (2008). Public-Private Delivery of Urban Water Services in Africa.

Kennedy, M. M. (1979). Generalizing from Single Case studies. Evaluation Review, 3(4), 661-678.

Khadaroo, I. (2014) The Valuation of Risk Transfer in UK School Public Private Partnership Contracts. The British Accounting Review, 46(2), 154-165.

Khoury, S. J. and Zhou, C. (1998). Country Risk: Existing Models and New Horizons. Handbook of International Banking, 13. 327.

Kwofie, T. E., Afram, S., \& Botchway, E. (2016). A critical success model for PPP public housing delivery in Ghana. Built Environment Project and Asset Management, 6(1), 58-73.

Liu, T., Wang, Y., \& Wilkinson, S. (2016). Identifying critical factors affecting the effectiveness and efficiency of tendering processes in Public-Private Partnerships (PPPs): A comparative analysis of Australia and China. International Journal of Project Management, 34(4), 701-716.

Merriam, S. B. (1998). Qualitative Research and Case Study Applications in Education. Revised and Expanded from" Case Study Research in Education.". Jossey-Bass Publishers, 350 Sansome St, San Francisco, CA 94104.

Mills, S., (2010). “The Mechanics of Project Finance”. Institute for International Research (IIR), Limited, U.K.

Mudi, A., Lowe, J., \& Manase, D. (2015). Conceptual Framework for Public-Private Financed Road Infrastructure Development in Nigeria. International Journal of Engineering Research \& Technology, 4(8), 586-590.

Ncube, M., (2010). Financing and Managing Infrastructure in Africa. Journal of African Economies, 19(suppl 1), pp.i114-i164.

Noor, K. B. (2008). Case study: A Strategic Research Methodology. American Journal of Applied Sciences, 5(11), 1602.

Nunnaly, J. (1978) Psychometric Theory. New York: McGraw-Hill.

Olsson, C. (2002). Risk Management in Emerging Markets. Financial Times and Prentice Hall, London. 
Oyedele, L., (2013). "Avoiding Performance Failure Payment Deductions in PFI/PPP Projects: Model of Critical Success Factors". Journal of Performance of Constructed Facilities, Volume 27, Issue 3 (June 2013), pp. 283-294.

Osei-Kyei, R., \& Chan, A. P. (2015). Review of studies on the Critical Success Factors for PublicPrivate Partnership (PPP) projects from 1990 to 2013. International Journal of Project Management, 33(6), 1335-1346.

Quiggin, J. (2004). Risk, PPPs and the Public Sector Comparator. Australian Accounting Review, $14(33), 51-61$.

Ramamurti, R. and Singh, J. V. (Eds.) (2009). Emerging Multinationals in Emerging Markets. Cambridge University Press.

Royal Society. (1983). Risk Assessment: Report of a Royal Society study group. London: Royal Society.

Sachs, T., Tiong, R. and Wang, S. Q. (2007). Analysis of Political Risks and Opportunities in Public Private Partnerships (PPP) in China and Selected Asian Countries: Survey Results. Chinese Management Studies, 1(2), 126-148.

Spector, P.E., 1992. Summated Rating Scale Construction: An introduction (No. 82). Sage.

Spillane, J.P., Oyedele, L.O., and von Meding, J. (2012) Confined Site Construction. Journal of Engineering, Design and Technology. 10(3), pp. 397-420. doi:10.1108/17260531211274747.

Tam, C.M., Deng, Z.M., Zeng, S.X., and Ho, C.S. (2000) Quest for Continuous Quality Improvement for Public Housing Construction in Hong Kong, Construction Management and Economics, 18(4), pp. 437-446. doi:10.1080/01446190050024851.

Santos, J.R.A., (1999). Cronbach's Alpha: A Tool for Assessing the Reliability of Scales. Journal of Extension, 37(2), pp.1-5.

Stake, R. E. (2013). Multiple Case Study Analysis. Guilford Press.

Vetiva, (2011). Construction Industry Report: A Haven of Opportunities. [Online] A publication of VETIVA Capital Management Limited. Accessed [18 February, 2015].

Wang, S. Q., Dulaimi, M. F., and Aguria, M. Y. (2004). Risk Management Framework for Construction Projects in Developing Countries. Construction Management and Economics, 22(3), 237-252.

World Bank Report (2013). Public Private Partnership Programme in Nigeria. Available from: [http://wwwwds.worldbank.org/external/default/WDSContentServer/WDSP/AFR/2013/12/27/ 090224b0821823a7/1_0/Rendered/PDF/Nigeria000Nige0Report000Sequence005.pdf]. [Accessed on 19th December, 2014].

Yin, R. K. (1994). Case Study Research: Design and Methods (2nd ed.). Thousand Oaks, CA: Sage Publication.

Yescombe, E. R. (2007). Public Private Partnership: Principles of Policy and Finance, 1st Edition. Oxford: Elsevier Limited. 